\title{
Oral health knowledge regarding dental caries among a group of middle school students
}

\author{
Cunoştinţe privind apariţia şi prevenţia cariei dentare în rândul unui grup \\ de elevi de gimnaziu
}

\author{
Ruxandra Sfeatcu', Roxana Oancea ${ }^{2}$, Cristian Dăguci ${ }^{3}$, Irina Maria Gheorghiu4, \\ Sânziana Adina Scărlătescu ${ }^{5}$, Paula Perlea ${ }^{5}$ \\ ${ }^{1}$ Disciplina de Sănătate Orală şi Stomatologie Comunitară, Facultatea de Medicină Dentară, \\ Universitatea de Medicină şi Farmacie "Carol Davila“, Bucureşti, România \\ 2Disciplina de Medicină Dentară Preventivă, Comunitară şi Sănătate Orală, Facultatea de Medicină \\ Dentară, Universitatea de Medicină şi Farmacie „Victor Babeş“, Timişoara \\ ${ }^{3}$ Disciplina de Prevenţie, Universitatea de Medicină şi Farmacie, Craiova, România \\ ${ }^{4}$ Disciplina de Odontoterapie Restauratoare, Facultatea de Medicină Dentară, \\ Universitatea de Medicină şi Farmacie „Carol Davila“, Bucureşti, România \\ ${ }^{5}$ Disciplina de Endodonţie, Facultatea de Medicină Dentară, \\ Universitatea de Medicină şi Farmacie „Carol Davila“, Bucureşti, România
}

\begin{abstract}
Introduction. Schools are favorable environment for information dissemination on disease prevention and supporting the health-related behaviors in oral education and promotion programs.

Material and methods. The study comprised 240 middle school students aged between 10 and 15 years, $57.5 \%$ of whom were female. Pupils received an anonymous questionnaire on the level of knowledge about risk factors for tooth decay and caries prevention methods and then an oral health experiential education lesson.

Results. The knowledge level is relatively high in terms of sugar consumption's and tooth brushing role on dental caries. Subjects are less informed about the involvement of the dental plaque and other risk factors. Family is the main source of oral health information, and many students rarely visit the dentist.

Conclusion. There is a need for preventive programs in schools, involving teachers and parents to develop a favorable environment to health education.
\end{abstract}

Keywords: tooth decay, knowledge, risk factors

\section{REZUMAT}

Introducere. Şcoala este un mediu favorabil pentru transmiterea informaţiilor referitoare la prevenirea îmbolnăvirilor şi susţinerea adoptării comportamentelor sanogene în cadrul programelor de promovare a sănătăţii orale.

Material şi metode. Studiul a cuprins 240 de elevi de gimnaziu cu vârste cuprinse între 10 şi 15 ani, 57,5\% fiind de sex feminin. Elevilor li s-a administrat un chestionar anonim de evaluare a nivelului de cunoştinţe privind factorii de risc şi prevenirea cariei dentare şi apoi li s-a prezentat o lecţie de educaţie experienţială pentru sănătatea orală.

Rezultate. Cunoştinţele elevilor sunt relativ crescute în ceea ce priveşte rolul consumului de zahăr şi al periajului dentar în apariţia, respectiv prevenţia cariei dentare. Subiecţii sunt mai puţin informaţi privind implicarea plăcii microbiene dentare şi a celorlalţi factori de risc. Familia este principala sursă de informare, mulţi elevi se prezintă rar la medic.

Concluzie. Se impune necesitatea unor programe preventive în şcoli, în care să fie implicaţi profesorii şi părinţii pentru a dezvolta un mediu favorabil educaţiei pentru sănătate.

Cuvinte cheie: caria dentară, cunoştinţe, factori de risc 


\section{INTRODUCERE}

Educaţia pentru sănătate are un rol important în obţinerea şi păstrarea unei stări corespunzătoare de sănătate orală prin promovarea unor informaţii medicale corecte şi pe înţelesul grupului ţintă (1). De aceea, se impune creşterea nivelului de cunoştinţe în ceea ce priveşte cauzele îmbolnăvirilor şi metodele de prevenire a afecţiunilor orale şi generale (2).

Principalele afecţiuni la nivelul cavităţii orale, caria dentară şi afecţiunile gingivale, sunt posibil de prevenit în măsura în care se aplică metodele de profilaxie primară prin resposabilizarea individului, dar şi a comunităţii din care acesta face parte $(1,3)$. Starea de sănătate orală este influenţată în mare măsură de cunoştinţele medicale, obiceiurile şi atitudinile faţă de igiena dentară personală, dieta şi comportamentul de adresabilitate la medic existente în familie $(1,4)$. Părinţii sunt modele pentru copiii lor şi au un rol important, alături de profesori, în formarea personalităţii şi a unei atitudini pozitive faţă de sănătate. În plus, copiii care sunt încurajaţi să meargă la cabinetul dentar sunt mai informaţi în ceea ce priveşte sănătatea orală $(5,6)$.

Studiile de specialitate au arătat că se impun programe de promovare a sănătăţii orale în şcoli şi grădinţe, cu implicarea profesorilor şi a părinţilor elevilor $(2,3,6)$. Astfel, se formează un stil de viaţă sănătos care se păstrează de-a lungul vieţii. Mai mult, prin educaţie pentru sănătate în mediul şcolar sunt cuprinşi mulţi elevi, inclusiv cei dezavantajaţi socio-economic sau cei care din teamă sau alte motive nu au un comportament adecvat de dispensarizare la medic. Şcoala este un mediu imporant pentru diseminarea informaţiilor referitoare la prevenirea îmbolnăvirilor şi susţinerea adoptării comportamentelor sanogene $(1,5)$.

Obiectivul principal al acestui studiu a fost evaluarea cunoştinţelor elevilor privind apariţia şi prevenirea cariei dentare, principala afecţiune orală la acest grup de vârstă.

\section{MATERIAL ŞI METODĂ}

În studiu au fost incluşi 240 de elevi de gimnaziu din Bucureşti, cu o distribuţie egală pe cele patru clase de studiu şi cu o pondere mai crescută a elevelor (57,5\%). Media de vârstă a fost de 12,49 ani (DS $\pm 1,27)$. În prealabil, s-a obţinut acordul directorilor şcolilor, iar părinţii au fost informaţi despre participarea elevilor la o lecţie de educaţie pentru sănătatea orală. Elevilor li s-au explicat scopul şi metodele de lucru, au fost asiguraţi de confidenţialitatea datelor, iar prin faptul că au răspuns la chestionar şi-au exprimat acordul de participare la studiu. Înainte de prezentarea unei lecţii de educaţie experienţială pentru sănătatea orală, elevilor li s-a aplicat un chestionar anonim de evaluare a nivelului de cunoştinţe privind factorii de risc implicaţi în apariţia cariei dentare. Studenţii din ultimul an ai Facultăţii de Medicină Dentară, supervizaţi de cadrele didactice, i-au implicat activ pe elevi în desfăşurarea interactivă a lecţiei de educaţie pentru sănătate.

\section{REZULTATE}

Datele obţinute sunt prezentate în tabele, atât pentru întreg lotul de studiu, cât şi în funcţie de genul respondenţilor şi clasa de studiu.

Cunoştinţele elevilor privind principalii factori de risc carios sunt crescute pentru consumul de zahăr, 85,5\% dintre elevi aleg această variantă de răspuns, mai ales fetele, dar fără diferenţe legate de nivelul de educaţie (Tabelul 1). Doar 47,5\% cunosc rolul plăcii microbiene dentare, mai mult elevele; nivelul de informare este influenţat de gradul de educaţie, corect răspund mai mulţi subiecţii de clasa a VIII-a şi a VII-a. Există şi un procent de 7,5\% dintre elevi care declară că nu cunosc factorii de risc implicaţi în apariţia cariei dentare. Se observă că nivelul de cunoştinţe este mai crescut la eleve şi pe măsură ce vârsta creşte (Tabelul 1).

Cei mai mulţi elevi implicaţi în studiu cunosc rolul periajului dentar personal în prevenirea apariţiei cariei dentare $(90,8 \%)$ (Tabelul 2). Fetele sunt mai informate decât băieții, iar nivelul este similar indiferent de anii de studiu (Tabelul 2).

Familia este principala sursă de informare în ceea ce priveşte sănătatea orală (în $85 \%$ dintre cazuri), medicul stomatolog pentru aproximativ o treime dintre elevi (37,5\%), iar şcoala este aleasă ca variantă de răspuns de doar 3,3\% dintre respondenţi (Tabel 3).

Elevele aleg în număr mai mare mediul familial ca sursă de informare medicală, iar în ceea ce priveşte celelalte două variante de răspuns nu se observă diferenţe (Tabelul 3). 
TABELUL 1. Cunoştințele elevilor privind factorii de risc implicați în apariția cariei dentare

\begin{tabular}{|l|c|c|c|c|c|c|c|}
\hline Factori de risc & $\begin{array}{c}\text { Lot total } \\
\mathbf{N}(\%)\end{array}$ & $\begin{array}{c}\text { Masculin } \\
\text { (N) }\end{array}$ & $\begin{array}{c}\text { Feminin } \\
\text { (N) }\end{array}$ & $\begin{array}{c}\text { Cls. VIII } \\
\text { (N) }\end{array}$ & $\begin{array}{c}\text { Cls. VII } \\
\text { (N) }\end{array}$ & $\begin{array}{c}\text { Cls. VI } \\
\text { (N) }\end{array}$ & $\begin{array}{c}\text { Cls. V } \\
\text { (N) }\end{array}$ \\
\hline Bacterii & $114(47,5)$ & 48 & 66 & 46 & 36 & 12 & 20 \\
\hline Consum de zahăr & $206(85,8)$ & 84 & 122 & 54 & 52 & 48 & 52 \\
\hline Afecțiuni generale & $14(5,8)$ & 4 & 10 & 4 & 4 & 4 & 2 \\
\hline Sarcină & $30(2,5)$ & 14 & 16 & 4 & 4 & 12 & 10 \\
\hline Ereditate & $12(5)$ & 8 & 4 & 2 & 2 & 4 & 4 \\
\hline Nu știu & $18(7,5)$ & 8 & 10 & 2 & 2 & 8 & 6 \\
\hline
\end{tabular}

TABELUL 2. Cunoştințele elevilor privind rolul periajului dentar personal

\begin{tabular}{|l|c|c|c|c|c|c|c|}
\hline $\begin{array}{l}\text { Rolul cariopreventiv } \\
\text { al periajului }\end{array}$ & $\begin{array}{c}\text { Lot total } \\
\text { N (\%) }\end{array}$ & $\begin{array}{c}\text { Masculin } \\
\text { (N) }\end{array}$ & $\begin{array}{c}\text { Feminin } \\
\text { (N) }\end{array}$ & $\begin{array}{c}\text { Cls. VIII } \\
\text { (N) }\end{array}$ & $\begin{array}{c}\text { Cls. VII } \\
\text { (N) }\end{array}$ & $\begin{array}{c}\text { Cls. VI } \\
\text { (N) }\end{array}$ & $\begin{array}{c}\text { Cls. V } \\
\text { (N) }\end{array}$ \\
\hline $\mathrm{Da}$ & $218(90,8)$ & 96 & 122 & 56 & 58 & 50 & 54 \\
\hline $\mathrm{Nu}$ & $16(6,7)$ & 6 & 10 & 4 & 0 & 8 & 4 \\
\hline $\mathrm{Nu}$ știu & $6(2,5)$ & 4 & 2 & 0 & 2 & 2 & 2 \\
\hline
\end{tabular}

TABELUL 3. Principalele surse de informare privind sănătatea orală

\begin{tabular}{|l|c|c|c|c|c|c|c|}
\hline Surse de informare & $\begin{array}{c}\text { Lot total } \\
\mathbf{N}(\%)\end{array}$ & $\begin{array}{c}\text { Masculin } \\
(\mathbf{N})\end{array}$ & $\begin{array}{c}\text { Feminin } \\
(\mathbf{N})\end{array}$ & $\begin{array}{c}\text { Cls. VIII } \\
(\mathbf{N})\end{array}$ & $\begin{array}{c}\text { Cls. VII } \\
(\mathbf{N})\end{array}$ & $\begin{array}{c}\text { Cls. VI } \\
\text { (N) }\end{array}$ & $\begin{array}{c}\text { Cls. V } \\
\text { (N) }\end{array}$ \\
\hline Familie & $204(85)$ & 84 & 120 & 56 & 50 & 46 & 52 \\
\hline Școală & $8(3,3)$ & 2 & 6 & 4 & 0 & 0 & 4 \\
\hline Medic dentist & $90(37,5)$ & 40 & 50 & 26 & 22 & 18 & 24 \\
\hline
\end{tabular}

Privind frecvenţa vizitelor la medicul stomato$\log , 60,8 \%$ declară că au fost la un cabinet dentar în ultimul an; o treime alege varianta de răspuns ,,cu mai mulţi ani în urmă“; 9 elevi nu au fost niciodată la medicul dentist $(7,5 \%)$ (Tabelul 4).

În ceea ce priveşte motivul prezentării la cabinetul de medicină dentară, cei mai mulţi elevi declară că au fost pentru tratament de specialitate, o treime pentru control şi 10,8\% pentru rezolvarea unei urgenţe (Tabelul 5).

Elevele se prezintă la cabinetul dentar pentru control mai mult decât subiecţii de sex masculin, pentru restul variantelor de răspuns nu se observă diferenţe.

\section{DISCUṬII}

Rezultatele prezentate arată că subiecţii incluşi în studiu cunosc rolul consumului de zahăr în apariţia cariei dentare, dar sunt mai puţin informaţi de rolul microorganismelor din cavitatea orală, doar aproximativ jumătate (47,5\%) aleg această variantă de răspuns. Un alt studiu realizat în Bucureşti arată un procent mai crescut de elevi $(80 \%)$ din acelaşi grup de vârstă care cunosc implicarea plăcii microbiene dentare (7).

Cea mai importantă sursă de informare privind sănătatea orală este familia ( $85 \%$ dintre elevi), date similare fiind arătate şi de alte studii $(8,9)$, dar exis-

TABELUL 4. Momentul ultimei vizite la medicul stomatolog în rândul elevilor din studiu

\begin{tabular}{|l|c|c|c|c|c|c|c|}
\hline $\begin{array}{l}\text { Adresabilitatea la } \\
\text { cabinet }\end{array}$ & $\begin{array}{c}\text { Lot total } \\
\text { N (\%) }\end{array}$ & $\begin{array}{c}\text { Masculin } \\
\text { (N) }\end{array}$ & $\begin{array}{c}\text { Feminin } \\
\text { (N) }\end{array}$ & $\begin{array}{c}\text { Cls. VIII } \\
\text { (N) }\end{array}$ & $\begin{array}{c}\text { Cls. VII } \\
\text { (N) }\end{array}$ & $\begin{array}{c}\text { Cls. VI } \\
\text { (N) }\end{array}$ & $\begin{array}{c}\text { Cls. V } \\
\text { (N) }\end{array}$ \\
\hline În ultimele 12 luni & $146(60.8)$ & 60 & 86 & 46 & 32 & 32 & 36 \\
\hline Cu ani în urmă & $76(31.7)$ & 32 & 44 & 10 & 16 & 26 & 24 \\
\hline Niciodată & $18(7.5)$ & 10 & 8 & 4 & 12 & 2 & 0 \\
\hline
\end{tabular}

TABELUL 5. Motivele ultimei vizitei la cabinetul de medicină dentară

\begin{tabular}{|l|c|c|c|c|c|c|c|}
\hline $\begin{array}{l}\text { Motivul prezentării } \\
\text { la medic }\end{array}$ & $\begin{array}{c}\text { Lot total } \\
\text { N (\%) }\end{array}$ & $\begin{array}{c}\text { Masculin } \\
\text { (N) }\end{array}$ & $\begin{array}{c}\text { Feminin } \\
\text { (N) }\end{array}$ & $\begin{array}{c}\text { Cls. VIII } \\
\text { (N) }\end{array}$ & $\begin{array}{c}\text { Cls. VII } \\
\text { (N) }\end{array}$ & $\begin{array}{c}\text { Cls. VI } \\
\text { (N) }\end{array}$ & $\begin{array}{c}\text { Cls. V } \\
\text { (N) }\end{array}$ \\
\hline Urgență & $26(10,8)$ & 12 & 14 & 8 & 6 & 12 & 0 \\
\hline Control & $88(36,7)$ & 26 & 62 & 20 & 22 & 26 & 20 \\
\hline Tratament & $126(52,5)$ & 68 & 58 & 32 & 32 & 22 & 40 \\
\hline
\end{tabular}


tă şi studii în care pe primul loc regăsim medicul stomatolog (7). Copiii sunt în mare parte dependenţi de părinţii lor în alegerea, cumpărarea şi utilizarea produselor de igienă orală şi a produselor alimentare, precum şi în utilizarea serviciilor de îngrijire a sănătăţii orale, de aceea este important nivelul de cunoştinţe medicale în rândul părinţilor elevilor (10).

Mediul şcolar ca sursă de informare pentru sănătatea orală are o pondere foarte mică, 3,3\%, respectiv $8,3 \%$ într-un studiu similar $(8,9)$, ceea ce demonstrează necesitatea implementării programelor de promovare a sănătăţii orale în şcoli $(5,6)$.

Mai mult, elevii din prezentul studiu se prezintă la medicul stomatolog mai ales pentru tratamente curative, pentru control doar o treime $(36,7 \%)$ şi chiar 10,8\% în urgenţe. Un studiu realizat în 2012 pe două loturi de elevi arată un procent de 9,6\% şcolari din Croaţia şi de 2,6\% din Italia care se prezintă la cabinetul dentar în cazul existenţei unor probleme sau al unor dureri la nivelul cavităţii orale (11). O treime dintre elevi $(36,7 \%)$ nu au fost la un cabinet de medicină dentară recent, în ultimul an; procente mai mici sunt prezentate de studiul anterior menţionat (14,1\% la elevii din Croaţia, respectiv $17,6 \%$ la italieni) (11).

Nivelul de cunoştinţe medicale este un precursor al comportamentului sanogen faţă de sănătatea orală (10). Educaţia pentru prevenirea afecţiunilor trebuie să înceapă din copilărie, să implice şi părinţii şi profesorii, alături de responsabilitatea personalului medical în diseminarea adecvată a unor informaţii de bază corecte (4).

Educaţia pentru sănătate orală din mediul familial, şcolar şi sistemul serviciilor medicale are un rol important în creşterea nivelului de informare la copii şi adolescenţi şi deprinderea unor practici sanogene care se vor menţine de-a lungul întregii vieţi $(1,11)$.

În prezentul studiu s-a evaluat nivelul de cunoştinţe al elevilor, dar se impune şi decelarea comportamentului legat de periajul dentar şi alimentaţia zilnică, acasă dar şi la şcoală, alături de o evaluare clinică - pentru a putea corela starea de sănătate orală cu nivelul de informare medicală şi practicile, sanogene sau nesanogene ale elevilor şi a veni în întâmpinarea necesităţilor de sănătate depistate (7).

\section{CONCLUZII}

Elevii din studiu au cunoştinţe relativ crescute în ceea ce priveşte rolul consumului crescut de zahăr în apariţia cariei dentare, dar şi referitor la rolul cariopreventiv al periajului dentar personal. Subiecţii sunt mai puţin informaţi privind implicarea microorganismelor din cavitatea orală şi a celorlalţi factori de risc cariogeni.

Familia este principala sursă de informare pentru elevi, iar mulţi se prezintă rar la medic. Implicarea părinţilor şi a educatorilor din şcoli în oferirea de informaţii, motivarea şi susţinerea unor comportamente sanogene contribuie semnificativ la creşterea nivelului de cunoştinţe medicale în rândul elevilor, la dobândirea unor practici corecte de igienă orală, alimentaţie şi adresabilitate la cabinetul de medicină dentară.

Implicarea părinţilor şi a educatorilor din şcoli în oferirea de informaţii, motivarea şi susţinerea unor comportamente sănătoase faţă de sănătatea orală contribuie semnificativ la creşterea nivelului de cunoştinţe medicale în rândul elevilor, la dobândirea unor practici corecte de igienă personală, alimentaţie şi adresabilitate la cabinetul de medicină dentară.

\section{Menţiune}

Toţi autorii au contribuţie egală în realizarea acestui articol.

\section{Mulțumiri}

Dorim să mulţumim elevilor şi profesorilor pentru participarea la studiu şi companiei Procter \& Gamble Mkt România pentru sprijinul acordat.

\section{BIBLIOGRAFIE}

1. Dumitrache AM, Sfeatcu IR, Buzea CM, Dumitraşcu LC, Lambescu DG. Concepte şi tendinţe în sănătatea orală. Editura Universitară „Carol Davila“, Bucureşti, 2009

2. Petersen PE. World Health Organization global policy for improvement of oral health - World Health Assembly 2007. Int Dent $J$ 2008; 58:115-121

3. Davidović B, Ivanović M, Janković S, Leĉić J. Knowledge, attitudes and behavior of children in relation to oral health. Vojnosanit Pregl 2014; 71(10): 949-956

4. Dumitraşcu L. Schimbarea atitudinilor şi comportamentelor faţă de sănătatea orală. Editura Universitară Carol Davila, Bucureşti, 2012 
5. Hanganu C, Dănilă I, Bârlean L, Murariu A, Mihailovici L, Săveanu I. School-based dental health considerations for program development. Oral Health and Dental Management in the Black Sea Countries 2004; III(3):4-10

6. Kwan SY, Petersen PE, Pine CM, Borutta A. Health-promoting schools: an opportunity for oral health promotion. Bull World Health Organ 2005; 83:677-85

7. Funieru $\mathrm{C}$, Tandără $\mathrm{A}$, Cuculescu $\mathrm{M}$, Comes $\mathrm{C}$, Panaitescu $\mathrm{E}$, Dumitriu A, Dumitriu HT. Knowledge of Bucharest school's pupils concerning oral health. Oral Health and Dental Management in the Black Sea Countries 2008;VII( 2):19-24

8. Sfeatcu R, Părlătescu I, Gheorghe C, Mihai L, Petre A, Dumitrache MA. Health literacy assessment among the adolescents. Medical Connection 2015; 10(4):49-51
9. Rusu-Negraia M, Dumitrache MA, Sfeatcu IR. Oral health behavior assessment among adolescents. Analele universității „Dunărea de jos“ din Galați. Medicină 2017. Fascicula XVII(2):49-54

10. Nucă C, Amariei C, Badea V, Jipa I. Relationships between Constanta (Romania) 12-year-old children's oral health status and their parents' socioeconomic status, oral health knowledge and attitudes. Oral Health and Dental Management in the Black Sea Countries 2009; VIII(4):44-52.

11. Ĉuković-Bagić I, Dumanĉić J, Nuzzolese E, Maruŝić M, Lepore MM. Oral health awareness in Croatian and Italian urban adolescents. Coll. Antropol. 2012; 36 (1): 221-226. 